\title{
The Use of COI in the Refugee Status Determination Process in the UK: Looking Back, Reaching Forward
}

\author{
Jo Pettitt, Laurel Townhead, and Stephanie Huber
}

Abstract

In the context of Refugee Status Determination (RSD), while the primary form of evidence is the testimony of the asylum applicant, objective evidence in the form of Country of Origin Information (COI) is recognized as an importantand potentially crucial-tool in decision making.

A research project of the Research and Information Unit (RIU) of the Immigration Advisory Service (IAS) examines the use of COI in the RSD process in the UK from initial decision to final appeal. The findings highlight the high level of inconsistency in the understanding of and the application of COI in RSD in the UK. It will demonstrate the need for this issue to be urgently addressed in the interest of just and effective decision making in the UK, and help inform discussions at the European and international levels.

\section{Résumé}

Dans le contexte de la Détermination du statut de réfugié (DSR), bien que la forme principale de preuve reste le témoignage du demandeur d'asile, des preuves objectives sous la forme de Country of Origin Information (COI) (" Information du pays d'origine ") est reconnue comme étant un outil important - et potentiellement très utile - pour le processus décisionnel.

Un projet de recherche $d u$ Research and Information Unit (RIU) ("Unité de recherche et de l'information") de l'Immigration Advisory Service (IAS) ("Service consultatif sur l'immigration ") examine l'utilisation du COI dans le processus du DSR au Royaume Uni, à partir de la décision initiale jusqu’à l'appel final. Les conclusions soulignent le niveau élevé d'incohérence dans la compréhension du COI et de son emploi dans le DSR au Royaume Uni. Elles démontreront l'urgent besoin de s'attaquer à ce problème afin quion puisse prendre des décisions justes et effectives au Royaume Uni, et aussi pour aider à guider les débats à l'échelle de l'Europe et au niveau international.

\section{Introduction}

The importance of the use of country information in Refugee Status Determination (RSD) processes is well established and generally accepted. However, a study of its use in the RSD process in the UK highlights the shortcomings of its usage in practice.

This paper will draw on the preliminary findings and recommendations reached by a project entitled The Use of Country of Origin Information in the Refugee Status Determination Process in the United Kingdom, which the Research and Information Unit (RIU) of the Immigration Advisory Service (IAS) ${ }^{1}$ is in the process of finalizing. ${ }^{2}$

The focus of this paper will be on the way in which country information is used in the process of determining asylum claims made in the UK.

This article will start by briefly examining country of origin information (COI) and its use in the RSD process before considering the findings reached through three individual studies that form the essence of the project. The three studies examine the use of COI in first and second instance decision making by focusing on Home Office policy documents (known as Operational Guidance Notes, or OGNs), Reason for Refusal Letters (RFRLs), and Appeal Determinations. Preliminary findings highlight an unacceptable level of inconsistency in the understanding and application of COI in the RSD process, and demonstrate the need for this issue to be addressed in order to enhance the process of determining asylum claims made in the UK. The findings of each of the studies will conclude with recommendations to decision makers on the way in which the use of COI can be improved in the interest of just and effective decision making. 


\section{Establishing a "Well-Founded" Fear: The Use of $\mathrm{COI}$}

Due to the highly complex and individual nature of asylum claims it cannot be assumed that decision makers at any level hold in their minds the necessary range and depth of information relating to all of the many countries of origin of asylum seekers whose status it falls to them to determine.

The principal role of COI in the RSD process is, therefore, to provide information which enables decision makers to assess whether an asylum seeker's subjective fear is based on objective circumstances. ${ }^{3}$ The need for this assessment is rooted in the concept of a "well-founded fear" contained in the refugee definition in Article $1 \mathrm{~A}(2)$ of the Refugee Convention. ${ }^{4}$

The UNHCR Handbook on Procedures and Criteria for Determining Refugee Status under the 1951 Convention and the 1967 Protocol relating to the Status of Refugees confirms that to establish whether a claim is "well-founded" calls for an objective assessment of the applicant's fear:

42. As regards the objective element, it is necessary to evaluate the statements made by the applicant. The competent authorities that are called upon to determine refugee status are not required to pass judgement on conditions in the applicant's country of origin. The applicant's statements cannot, however, be considered in the abstract, and must be viewed in the context of the relevant background situation. A knowledge of conditions in the applicant's country of origin-while not a primary objective-is an important element in assessing the applicant's credibility. In general, the applicant's fear should be considered well-founded if he can establish, to a reasonable degree, that his continued stay in his country of origin has become intolerable to him for the reasons stated in the definition, or would for the same reasons be intolerable if he returned there. ${ }^{5}$ (Emphasis added.)

Furthermore, a 2004 UNHCR report on COI states:

9. The information needed to assess a claim for asylum is both general and case specific.

Decision makers must assess an applicant's claim and his/her credibility and place his/her "story" in its appropriate factual context, that is, the known situation in the country of origin. Credibility assessment is itself a function of best judgement, facts and the interviewer's ability to draw appropriate inferences. To aid the decision-making process, the COI used needs to be as accurate, up-to-date and comprehensive as possible. ${ }^{6}$ (Emphasis added.)

In October 2006, changes to the Immigration Rules were introduced in the UK, which set out in detail the criteria for granting asylum or humanitarian protection, based on the EC Council Directive 2004/83/EC (EU Qualification Directive). ${ }^{7}$ Article 4 of the EU Qualification Directive deals specifically with "Assessment of facts and circumstances" relating to a claim for international protection, whilst Article 4(3) highlights the importance of COI to decision makers as follows:

The assessment of an application for international protection is to be carried out on an individual basis and includes taking into account:

(a) all relevant facts as they relate to the country of origin at the time of taking a decision on the application; including laws and regulations of the country of origin and the manner in which they are applied $[\ldots]^{8}$ (Emphasis added.)

Furthermore, a paper prepared for the International Association of Refugee Legal Judges (IARLJ) Biennial World Conference in November $2006^{9}$ on judicial criteria for assessing COI states:

1. In the course of dealing with asylum appeals judges will depend to a great extent for their ability to make sound judgments on having before them up-to-date and reliable country background information or "Country of Origin Information" (COI). The probative value of an asylum seeker's evidence has to be evaluated in the light of what is known about the conditions in the country of origin. ${ }^{10}$ (Emphasis added.)

As has been demonstrated, it is both accepted and understood at the highest level that COI should assist the decision maker in both assessing claimants' credibility and in assessing whether they might be at future risk of persecution if returned to their country of origin or any other (relevant) third country. More problematic is the issue of what constitutes $\mathrm{COI}$ and how it is put to use by decision makers themselves.

\section{What Is COI; What Is the Problem with COI?}

A number of issues identified through the research project ${ }^{11}$ are underpinned by the fundamental problem of the lack of a clear understanding of the role and limits of COI in providing "factual" evidential support in asylum determinations. This is rooted, to an extent, in the more basic problem of "what is COI"?

Although COI is the most commonly used term, and the one adopted in this paper, in the UK there is no uniformity in the description of material about the countries where asylum seekers come from or have passed through. Such material may be referred to as country information, country of origin information, country materials, country evidence, objective evidence, or country bundles.

(C) Jo Pettitt, Laurel Townhead and Stephanie Huber, 2008. This open-access work is licensed under a Creative Commons AttributionNonCommercial 4.0 International License, which permits use, reproduction and distribution in any medium for non-commercial purposes, provided the original author(s) are credited and the original publication in Refuge: Canada's Journal on Refugees is cited. 
According to the Austrian Centre for Country of Origin and Asylum Research and Documentation (ACCORD), COI in the asylum process is:

[Any information that] should help to answer questions by decision makers and legal advisers about the political, social, cultural, economic and human rights situation as well as the humanitarian situation in countries of origin. ${ }^{12}$

Potential sources of COI may span many academic and professional disciplines since there is no independent field of study that defines or delimits what is and what is not classifiable, or usable, as COI for the purposes of RSD. A source of information only becomes COI when it is used as such in RSD processes and is not, for the most part, produced for use in the asylum process. Materials sought to be relied upon as COI may have been prepared in academic, policy, or campaigning environments in which notions about fact and objectivity differ from those used in the legal context. ${ }^{13}$ All this has significant bearing on why asylum decision makers often appear dissatisfied with the content and/or presentation of country information sources and on why there is an uncomfortable level of uncertainty and inconsistency in the submission and treatment of these materials.

"Objective facts," ready to be applied to the specifics of the case in hand, are rarely found in COI materials. ${ }^{14}$ Interpretation of COI in light of the circumstances of the case will therefore almost always be required. However, the interpretative step involved in bringing relevant COI to bear on specific cases is opaque. The decision maker will seek to make objective "findings of fact" about different aspects of a claimant's case. ${ }^{15}$ Where this involves consideration of documentary evidence, including COI, it must first be decided what weight to attach to the available sources, before determining on their precise application to the questions at hand. When competing and inconsistent versions of the factual situation are presented, the decision maker must award preference to one source (which might include the claimant's own account) over another.

In light of this, it is apparent that the process by which quality standards are applied to the selection of sources of COI, and by which sources are weighted and then applied to the case in hand, are of critical importance. While some efforts to address this issue have been made, ${ }^{16}$ a coherent approach has yet to emerge among practitioners and decision makers alike, resulting in the high level of inconsistency and uncertainty mentioned above and demonstrated in the remainder of this paper.

\section{The COI Research Project}

The Research and Information Unit (RIU) of the IAS is currently in the end phase of a project entitled "Using country of origin information to improve decision making." From the outset, the title implied three important assumptions:

1. There are currently problems with or there is room for improvement in decision making, at any or all levels (i.e., from initial decision through to final appeals).

2. COI is in some sense under-used or the (mis-) use of $\mathrm{COI}$ is a contributing factor in the current problems in decision making.

3. Using COI differently would result in improved decision making.

Consequently, the project's main aim is to contribute in a positive manner to improving the quality of decision making in RSD in the UK, by examining the use of COI (e.g. nature, purpose, source, application) from initial decision to final appeals.

The project consists of three main parts:

1. conceptualizing COI and its use in RSD;

2. examining IAS caseworkers' use of COI, especially with regard to merits testing; and

3. individual studies focusing on the use of COI in first and second instance decision making through studies of Home Office policy documents (Operational Guidance Notes (OGNs), Reason for Refusal Letters (RFRLs), and Appeal Determinations).

The remainder of this paper will focus on part 3 of the project, examining the use of COI in first and second instance decision making.

Preliminary findings highlight the high level of inconsistency in the understanding and application of COI in the RSD process, and demonstrate the need for this issue to be addressed in the interest of just and effective decision making in the UK. Although UK-focused, some of the findings reflect the reality in other countries. This article highlights areas of concern and draws out key recommendations which can, hopefully, be applied universally.

\section{The Operational Guidance Note Study}

According to the UK Border Agency's website OGNs provide a "brief summary of the general, political and human rights situation in the country." 17 Their primary purpose is to provide "clear guidance on whether the main types of claim are likely to justify the grant of asylum, humanitarian protection or discretionary leave." 18 The COI contained in OGNs is sourced from "the most recent country of origin information" produced by the Home Office COI Service (COIS), part of the Research Development and Statistics (RDS) branch of the Home Office, which is removed from the asylum policy 
and decision-making process. ${ }^{19}$ The OGNs are produced by the Country Specific Asylum Policy Team (CSAPT), which is part of another branch at the Home Office, the Asylum and Appeals Policy Directorate (AAPD).

Consequently, OGNs can be summarized as follows:

- OGNs are policy documents;

- $\quad$ OGNs do provide COI; and

- the COI is selected for a specific application.

The latter point is confirmed by the Home Office in a response to the Advisory Panel on Country Information (APCI) in February 2007. ${ }^{20}$ In the note, ${ }^{21}$ the Home Office explained that the "OGNs are policy guidance documents rather than COI documents; and the country material within them is specifically selected to support that policy function." 22 It further explains that

\footnotetext{
The country material cited in OGNs is selected / summarised specifically in order to provide sufficient explanation-alongside wider policy considerations and case law - of the guidance given on particular categories of claims. This country material does not seek to provide detailed information on all aspects of an issue and is not a substitute for the COI provided in COIS products. OGNs explicitly instruct decision makers to refer to the relevant COIS product/original sources for the full picture. ${ }^{23}$
}

The project included this particular study since OGNs are seen and used as consultation and even first-decisionmaking tools by Home Office case workers. A study commissioned by the Home Office in $2003^{24}$ and discussions within the $\mathrm{APCI}^{25}$ suggest that limited time to assess claims may prompt Home Office caseworkers to rely on the minimum amount of country information possible, with some caseworkers only referring to the OGN.

At the outset the main concern of this study was with the COI component of the OGN on which policy decisions are based, and was not to contest the policy conclusions that the CSAPT has drawn.

Due to limited time available six OGNs were selected amongst the existing fifty-two. Despite the constraints of a limited sample all OGNs examined raised similar observations and issues of concern. Furthermore, the six OGNs are representative: some of them are complemented by or draw their country information from COI products produced by the Home Office COIS, ${ }^{26}$ whilst others do not.

The countries covered are: Afghanistan, Israel, Gaza and the West Bank, Kenya, Nigeria, Uganda, and Zimbabwe.

The six sample OGNs enabled us to reach the following conclusions:

- The country information often fails to reflect the full range of current sources on an issue of critical importance to decision makers. Despite the fact that the Home Office might argue that OGNs are only intended to be seen as policy guidance documents, the reality is that some caseworkers might solely refer to OGNs and hence only see the COI that is provided in them. OGNs have also been used as a source of COI by immigration judges. Given the Home Office's own statement quoted above that COI in OGNs is not a substitute for other COI, and the limitations with the COI described below, this is a worrying trend.

- The country information relies heavily on the respective Home Office COIS Report. Home Office COIS reports have often been criticized for being out of date and are a collation or summary of COI material published by others. ${ }^{27}$ Since OGNs rely greatly on direct quotations from "secondary" sources of COI Reports, it would be more appropriate to quote directly from the original source and reference them accordingly.

- The country information is selected for a specific application, which distorts the reality in the country of origin and results in misleading conclusions. It became apparent that in the OGNs that were examined the language used painted a less dire situation in the country of origin than the original sources or even the Home Office COIS reports suggest. Moreover, it becomes apparent that certain information was omitted to fit the sought policy conclusion.

- Policy conclusions do not appear to be consistently supported by the presented COI. Despite the fact that it was not the purpose of this study to contest the policy conclusions in OGNs, it is necessary to observe that certain policy conclusions are drawn in OGNs which are not supported by the selected and presented COI.

- The "facts/findings" on a country are not always substantiated by the referenced sources. Generally poor, unclear, and incorrect footnoting and referencing made it difficult to double-check where the country information was taken from. This showed a lack of transparency, which is one of the four pillars of a proper COI research methodology, along with relevance; reliability and balance; and accuracy and currency. ${ }^{28}$

A possible approach in overcoming these shortcomings would be to advocate for the removal of COI from OGNs and include the conclusions only. According to the Home Office's response to the APCI in February 2007, the format and content of OGNs are "currently being reviewed" and a key aim "will be to reduce the country material in OGNs to the minimum necessary for the understanding of the guid- 
ance. This will ensure that users refer to the relevant COI Service product for COI." 29 Moreover, the amount of COI material in OGNs for which there are no "[ ... ] COIS COI products-has become more extensive than envisaged. To avoid this, in future, a COI product will be produced for all countries for which there is an OGN." 30

This would be an important improvement since through the work of the Research and Information Unit at IAS several distinct misuses of country information contained in OGNs have been observed. Firstly, the study on the use of COI in Reason for Refusal Letters (RFRLs) shows that out of eightythree RFRLs examined, the OGN was used and cited as a source of COI in seventeen cases. In seven of these cases, the OGN was the only source of COI that was made reference to in the RFRL and in all of these cases the COI was insufficient to address the specific issues of the case. Secondly, the study on the use of COI in Appeal Determinations has so far found that in one instance out of eleven determinations examined ${ }^{31}$ the OGN has been used as a source of COI. ${ }^{32}$ Moreover, in a January 2007 judgment by the European Court of Human Rights, ${ }^{33}$ the Court relied on several occasions on COI contained in the May 2006 OGN for Somalia to substantiate its finding that a particular group was at risk on return and not able to internally relocate. ${ }^{34}$ Lastly, a March 2007 Angolan Response to Information Request (RIR $)^{35}$ and a September 2006 Albanian RIR ${ }^{36}$ by the Immigration and Refugee Board of Canada (IRBC) referred to country information contained in the Angolan and Albanian OGN respectively as part of their research answer on whether human rights abuses still continue in the Angolan enclave of Cabinda and whether state protection is available to homosexuals in Albania. ${ }^{37}$ No specific reference was made to the fact that this particular piece of COI was taken from a policy document.

The main conclusion to emerge from this study is that the COI provided in OGNs should not be seen as country information or as objective evidence. OGNs should be used with caution and with an awareness of their stated purpose: The COI in OGNs exists as part of a policy document produced by a domestic governmental body responsible for RSD in an adversarial system. Notwithstanding the concerns described above as to the quality and transparency of the COI in OGNs, their objectivity must be questioned. Taken out of context the country information contained in OGNs might invite further misuse.

\section{The Reason for Refusal Letter Study}

Initial decisions on applications for asylum in the UK are made by Home Office caseworkers-case owners since April 2007 under the New Asylum Model (NAM) - and are based on the applicant's screening interview record, the Statement of Evidence Form, and the full interview record. Decisions may also incorporate further representations, including objective evidence in the form of COI, from the applicant's legal representative.

According to the Home Office Asylum Policy Instructions case owners are instructed and obliged to access and make use of COI in considering and deciding an application for asylum. ${ }^{38}$

The decision to refuse an application is given in the form of a Reason for Refusal Letter (RFRL). The RFRL should set out the applicant's case and present the findings and decision of the Home Office set against objective evidence. ${ }^{39}$

Quality concerns about the initial decision-making process have been widely expressed in the UK, for example, by Amnesty International and the Medical Foundation for the Care of Victims of Torture (Medical Foundation). ${ }^{40}$ Such concerns, among others, have been specifically addressed since 2005 in the form of the Quality Initiative (QI) project conducted by UNHCR within the Home Office. ${ }^{41}$ Above all, the Home Office has also committed itself to the improvement of initial decision making in the introduction of the New Asylum Model. ${ }^{42}$

However, the experience of IAS COI researchers, based on case specific COI research conducted for approximately one hundred asylum cases per month, suggests that the use of COI in initial decision making, as reflected in RFRLs, remains problematic. Specific areas of concern are:

- consistency in the use of COI,

- adequacy of referencing of COI, transparency of sources,

- $\quad$ appropriate selection of COI, and

- application of COI to case related questions

The RFRL study examined in depth a sample of eightythree RFRLs for eight "asylum producing" countries over a six-month period, dating from January 2007 to June 2007, with the aim of eliciting objective data about the use of COI in initial decision making. The RFRLs were selected from the cases of IAS clients only and are therefore not necessarily taken to be representative of all asylum cases. It was anticipated that data extracted from this sample might reflect changes that have been undertaken by the Home Office, both in respect of the QI project and in the initial phase of the implementation of the New Asylum Model, since the data set represents a fairly even split between pre- and post-NAM decisions.

The sample RFRLs were taken from five of the countries most frequently represented in IAS cases, all of which fall within the Home Office "top twenty" asylum-producing countries. Regularly updated full Home Office COIS Reports are available to Home Office caseworkers for all these countries. These reports are themselves under the scrutiny of the APCI. The selected countries are as follows: Afghanistan, 
Democratic Republic of Congo (DRC), Iran, Somalia, and Zimbabwe.

A small subset of RFRLs were also examined from countries outside the Home Office "top 20," for which Home Office COIS Reports are not available. For those countries that still fall within the "top 50" asylum-producing countries, Home Office COI Bulletins are available to caseworkers. For those that fall outside this group, it is assumed that COI material is only available through the Home Office COIS case specific research service. This service can only be accessed with the approval of a Senior Caseworker. The selected countries in these categories are as follows: Cote d'Ivoire (Home Office COI Key Documents), Guinea (Home Office COI Key Documents), and the Occupied Palestinian Territories (Israel) (no Home Office COI product available).

The RFRLs study enabled us to reach the following conclusions:

\section{The Use of COI in RFRLs}

Of the total number of eighty-three RFRLs considered in the sample, fourteen made no reference to COI at all. Of the seventy-two RFRLs relating to countries for which there are Home Office COIS Reports available (Afghanistan, DRC, Iran, Somalia, and Zimbabwe), twelve made no reference to COI. ${ }^{43}$

The absence of any reference to COI in all these cases suggests either that there is a level of complacency about the caseworker's knowledge of the situation in the country of origin or that COI sources were consulted but that it was not considered important to cite or properly reference them. It might be further concluded that the failure to make use of COI indicates a complete disregard for its importance in the RSD process.

\section{The Extent of Use of COI in RFRLs}

As an indication of the extent of use of COI, where reference was made to COI in the RFRLs, on average it was referred to in four of the numbered paragraphs. ${ }^{44}$ However, across all the RFRLs and the various countries, the number of paragraphs in which COI was used ranged from one to eighteen, reflecting the relatively wide variation in the extent to which COI was made use of across the sample.

\section{Home Office COI Products: Reference to COI Sources in RFRLs}

Of the data sample selected for this study, five countries have Home Office COIS Reports (Afghanistan, DRC, Iran, Somalia, and Zimbabwe), two countries have Home Office COIS Key Documents (Cote d'Ivoire and Guinea), and one has no country information provision (Occupied Palestinian
Territories). There are Home Office COIS Bulletins available for Afghanistan (dated December 2005); Zimbabwe (dated April, June, and November 2005) and Cote d'Ivoire (dated November 2004).

It was assumed that use of country information resources as specified above would be indicated by citation in the RFRL. On this basis it was found that of the seventy-two RFRLs for countries with Home Office COIS Reports, only forty-four made direct references to these reports; twentyeight therefore did not. As stated above, twelve RFRLs made no reference to COI, leaving sixteen, which made some reference to COI, although the sources were not specified, and not cited to COI products. Home Office COIS case specific research service was cited on seven occasions. ${ }^{45}$

\section{Operational Guidance Notes as a Source of COI}

As mentioned previously, data from the present study indicates that some caseworkers/case owners are still using OGNs as a source of COI and, in some instances, as the only source of COI. Of the data sample of eighty-three RFRLs, the OGN was used as a source of COI in seventeen cases. In seven of these cases, the OGN was the only source of COI that was made reference to in the RFRL and in all of these cases the COI was insufficient to address the specific issues of the case, the common pattern being that the case was refused on credibility grounds, in some cases on the basis of speculative argument. The use of OGNs as a source of policy guidance in decision making was not made explicit in any of the RFRLs where OGNs were cited.

\section{Referencing of $\mathrm{COI}$}

Across the entire sample of sixty-nine RFRLs which made any reference to $\mathrm{COI},{ }^{46}$ only twenty RFRLs had at least one source correctly referenced. In this case "correctly referenced" is taken to mean the inclusion of the source author, the name of the report and the date of publication. For ease of access to COI material cited, report section and paragraph numbers should also be stated. While these are generally stated when direct reference is made to Home Office COIS Reports (the Home Office COIS Report paragraph is stated, not the relevant paragraph in the original source), they are not stated in any other instances.

When Home Office COIS Reports are cited as COI source material in RFRLs, the original source document and author is often not stated (twenty-three instances). Similarly, the date of the original source ${ }^{47}$ is not stated in many cases (nineteen instances) which is particularly relevant given that the Home Office COIS Reports are compilations of sources including material spanning many years.

On the other hand, in a significant number of instances COI sources are cited in the RFRL, but it is not stated 
whether they have been extracted from the relevant Home Office COIS Report or have been independently sourced (11 instances). In other words, in some cases objective material is referenced to the Home Office COIS Report with no acknowledgement of the original source, while in others the material is cited to its original source but the Home Office COIS Report is not referenced. This demonstrates a lack of consistency and coherence in the approach of caseworkers/ case owners to referencing COI and undermines the ability of the asylum applicant and the applicant's representative to verify the objective evidence, and if necessary, contest the conclusions drawn.

Beyond the citing of COI from the Home Office COIS Reports, in a significant number of instances, no source at all was given for country information referred to in the RFRL. In a total of twelve instances across all the RFRLs where COI was used (sixty-nine), the source origin was either not stated at all or the information given was incomplete (did not contain either the source author or the name of the report). In a further four instances, while the source name and author was stated, the date of the source was not given. This is in clear contradiction of the Home Office Asylum Process Manual. ${ }^{48}$

The data set in this study, however, revealed that caseworkers/case owners used no standardized form of referencing of COI. Referencing of sources appears to be carried out on an ad hoc basis. Moreover, in a significant number of instances, sources of COI were not referenced at all, or not in any meaningful way.

\section{Relevance, Sufficiency and Accuracy of Use of COI}

It was noted in the First Report of the QI Project in February 2005 that COI used by Home Office case workers is frequently both out of date and inadequate for refugee status determination and that it was a matter of some concern to UNHCR that some decisions (both grants and refusals) do not make any reference to COI. ${ }^{49}$

There continues to be a consistent pattern of under-use of COI by initial decision makers to address both contextual issues and case specific questions that arise in individual asylum claims, as evidenced by the citation of COI in RFRLs. For example, in Afghan cases refusal decisions consistently state that there is an internal flight alternative to Kabul, although this is not supported by current and sufficient COI, which is related to the individual profile of a claimant.

Moreover, there is a tendency to use standard paragraph excerpts from Home Office COIS Reports to address particular issues, which do not always support the conclusions drawn or address the specifics of the case.

Due to the overall inadequacy of referencing, it is difficult to assess the temporal relevance of much of the COI materi- al cited in RFRLs. However, many instances were recorded where COI material cited was outdated despite the fact that newer material is clearly available in the public domain. For example, a 2005 report was used in one instance as a source of COI on the Taliban in Afghanistan for a RFRL dated June 2007. Where COI is sourced to Home Office COIS Reports, the date of the Home Office COIS Report is given (usually the most recent), but this does not accurately reflect the currency of the original source material, which may be considerably older.

Additionally, COI is used inaccurately on a significant number of occasions to support unfounded conclusions about the credibility of a claimant or the nature of the risk they may face. For example, in an Iranian case it is stated that because there is COI evidence that security services have killed many people, they would not be likely to give medical treatment to those detained, and, since the claimant stated that he was in detention and received medical treatment, he could not have been detained. In a Guinean case it was stated that the UN Committee on the Elimination of Discrimination Against Women (CEDAW), whose comments on the country's periodic report were cited as a source of COI, would be able to provide protection and redress for the individual claimant, who feared being forced to undergo female genital mutilation (FGM) if returned to Guinea.

\section{Use of Speculative Argument and Credibility Findings Not} Substantiated by COI

The use by initial decision makers of speculative argument was highlighted by the UNHCR QI team in their second report to the Home Office Minister in February 2006. In particular, initial decision makers were criticized for "attempting to guess the thought process of a third party" and for making findings of "implausibility" based on little or no evidence. UNHCR further comments that caseworkers tend to apply a "narrow UK-perspective when assessing events alleged to have taken place in significantly different cultural, political and social contexts." 50

Unfortunately, evidence from this study suggests that this tendency persists. Speculative argument of the type described by UNHCR was found to have been employed in twenty-eight of the eighty-three RFRLs in the sample, and on occasions a claimant's entire account is dismissed as incredible on the basis of cumulative speculative argument.

The following is an example of a DRC case:

[ ... ] It should be noted that by your own admission, you have stated that between April/May 2004 and April/May 2006 there were no physical attacks on you or your family. It is considered that if you were being persecuted to the degree that you describe by Mai Mai militia because of your imputed Nationality then a 
far more consistent pattern of persecution would have occurred. It is not considered credible that after going to the trouble of attacking your family in 2004, the militia would have then allowed you and the rest of your family to reside in peace for two years until they perpetrated the next attack.

To summarize, the conclusions from this particular study have raised the following key areas of concern with regards to the use of COI in RFRLs:

1. COI appears not to have been used at all in a significant number of initial decisions on asylum claims represented in this sample.

2. Where COI is used there is a huge discrepancy between different caseworkers'/case owners' use of COI in terms of the extent of its use, whether it is used to provide context or answer case specific points of fact or to establish credibility, etc.

3. OGNs continue to be used as a source of COI in initial decision-making, against the Home Office's own guidance.

4. There is no consistent pattern of referencing of COI sources used in the initial decision-making process. Some sources are not referenced at all while many others have incomplete reference, which lack either a date or a source author for example. In particular, sources which cite the Home Office COIS Reports in most cases do not state the original source author or date, which makes it difficult to assess the temporal relevance of the material and the weight of the source.

5. There is a consistent pattern of under-use of COI by initial decision makers to address both contextual issues and case specific questions that arise in individual asylum claims, as evidenced by the citation of COI in RFRLs. Furthermore, there is a tendency to use standard paragraph excerpts from Home Office COIS Reports to address particular issues, which do not always support the conclusions drawn or address the specifics of the case.

6. There is persistent use of outdated and undated COI material, as evidenced by sources cited in RFRLs, where newer material is clearly available in the public domain. Where COI is sourced to Home Office COIS Reports, the date of the Home Office COIS Report is given (usually the most recent), but this does not accurately reflect the currency of the original source material, which may be considerably older.

7. COI is used inaccurately on a significant number of occasions to support unfounded conclusions about the credibility of a claimant or the nature of the risk they may face.

8. Initial decision makers regularly make use of speculative argument, without reference to COI, to dismiss aspects of a claimant's account and credibility or the claim in its entirety.

From this it follows that in order to improve the use of COI in RFRLs, initial decision makers should make full use of COI in the consideration of all asylum claims. Where sufficient, relevant, and current COI is not available from existing Home Office COIS Reports and Home Office COIS Bulletins to address case specific questions, full use should be made of the case specific research service offered by the Home Office COI country officers. Secondly, sources cited in the RFRL or consulted in the course of making the initial decision in an asylum claim should always be referenced in full. This includes sources that are cited from Home Office COIS Reports. The original source should be stated, including author, title of the report, and date, as well as relevant section or paragraph numbers. Thirdly, OGNs should never be used as a source of COI in the initial decision-making process. Fourthly, COI should be used where necessary to address contextual issues as well as for the assessment of case specific questions in relation to the credibility of a claimant's account as well as the assessment of future risk, should the claimant be returned to his or her country of origin. Lastly, the use of speculative argument, as opposed to reasoned argument based on objective factors, should not be tolerated under any circumstances in the initial decision-making process.

\section{The Appeal Determination Study}

A further strand of the project concerns the use of COI by immigration judges in first instance asylum appeal determinations. Asylum applicants can appeal to the Asylum and Immigration Tribunal if their application is refused by the Home Office. The study focuses on the use of COI in unreported cases, which form the bulk of asylum determinations. A later task will be to examine Country Guidance cases to see if the treatment of COI in such cases is substantially different to that in unreported determinations. ${ }^{51}$

The study's sample is drawn from the same countries as the sample in the Reason for Refusal Letter study described above. This includes five countries for which Home Office COIS Reports are produced, two for which Home Office COIS Key Documents are listed, and one for which no COI product has been produced: Afghanistan, DRC, Iran, Somalia, Zimbabwe, Cote d'Ivoire (Home Office COIS Key Documents), Guinea (Home Office COIS Key Documents), and the Occupied Palestinian Territories (Israel) (no Home Office COI product available). 
The sample includes determinations promulgated over the last five years and draws on a range of hearing centres. At the time of writing only a quarter of the sample has been processed; therefore the findings are limited to preliminary observations.

\section{Use of COI}

Either COI as a broad category of evidence or specific COI reports have been referred to by the immigration judge in all of the determinations examined thus far. The extent to which such information is used varies greatly, from a cursory reference in respect to one of several issues at stake to a detailed consideration of a variety of sources.

\section{Purpose}

In the majority of determinations considered, immigration judges are using COI for context in order to better assess the credibility of the applicant's story and to judge their future risk. In a smaller number of cases COI is used to make decisions on case specific issues of fact, such as the level of authority of named individuals.

\section{Sources and Assessment of COI Material}

Thus far only one determination has made no mention of a Home Office COI product, either the Home Office's COIS Report, or in older cases, the Country Information and Policy Unit (CIPU) Report. ${ }^{52}$ All other determinations rely heavily, if not exclusively, on Home Office-produced COI.

In two cases where it is known that IAS's Research and Information Unit produced bundles with over thirty sources, only the Home Office COIS Report was explicitly referred to. In neither determination was any indication given as to why this one source had been relied on where others had not.

There is little or no consideration of the relative merits of various sources recorded in the determinations. It is, therefore, difficult to know if the reliance on COI produced by the Home Office instead of other sources is due to a thorough reflection on the evidential value of the sources submitted or because of some other reason such as familiarity.

\section{Use of Home Office Operational Guidance Note as COI} Of particular concern is the use in one of the determinations of an OGN as a source of COI. The immigration judge quoted from the OGN and wrongly attributed the information to the "COIS Bulletin 2005." However, there is no Home Office COIS Bulletin for 2005 and the language appears in the OGN exactly as quoted in the determination. This suggests a lack of understanding on the part of the immigration judge as to the different purposes of OGNs and Home Office COIS Bulletins.

\section{Transparency}

In most determinations the extent of the COI before the immigration judge and which party submitted what material is unclear. Many of the determinations contain statements of fact/situation with no reference to the evidence on which the statement is based; it is therefore unclear how the immigration judges came to such conclusions.

Moreover, in most determinations where sources are referred to, the references are not clear. For example, a reference may simply be "in the Country Assessment" with no indication of publisher, date, or paragraph number, making it difficult or impossible to assess whether the information has been accurately summarized and used as a basis for decisions.

This lack of transparency with respect to the country evidence that has been considered, makes it difficult to gain a clear understanding of the process by which immigration judges choose to accept the reports of one organization over those of another. Without this information it is difficult for applicants or their legal representatives to know which COI sources (e.g. US State Department Reports or Amnesty International Reports) or which types of COI (e.g. news articles, UN agency assessments, NGO reports) an immigration judge is likely to respond favourably to and which are likely to be given little weight.

\section{Lack of Information as a Basis to Make a Decision}

In some cases the immigration judge states that there is a lack of evidence in regard to an aspect of the case and makes a finding based upon that lack of information. For example, in one determination the immigration judge states, "There is no objective evidence before me to satisfy me that [MA] is a man of power and influence in Kabul or elsewhere," and thus finds that the applicant is not at risk from this individual.

It may be that in some instances a lack of evidence is evidence in itself but these circumstances will be limited and will require thorough research to have taken place which has found no relevant information. It cannot be assumed that COI will provide evidence of all individual persecutors, even where they are stated to be in positions of power.

The following recommendations are based on the preliminary findings outlined above and will be expanded upon in the final report on the project once this strand has been completed:

1. A full list of COI sources submitted should be annexed to the determination as has happened in some Country Guidance cases.

2. The basis of findings relating to country situation should be clearer, i.e. the source material that leads to that particular conclusion should be referenced. 
3. Referencing should be full and clear (title, publisher, date, and section or page number where appropriate).

4. Any assessment of sources that considers some to be of greater reliability than others should be made explicit.

\section{Conclusion}

From the outset of this study three assumptions were made: firstly, that there are currently problems with, or there is room for improvement in, decision making in the UK RSD process; secondly, that COI is in some sense under-used or that the (mis-)use of COI is a contributing factor in the current problems in decision making; and lastly, that using COI differently would result in improved decision making.

The preliminary findings from the three individual studies have so far demonstrated that these initial concerns were well-founded and have highlighted serious shortcomings in the use of COI in the RSD process in the UK.

It has been clearly established that COI plays a crucial role in $\mathrm{RSD}$, in providing information which enables decision makers to assess whether an asylum seeker's subjective fear is based on objective circumstances. However, it has also been demonstrated, through empirical study, that a coherent and consistent approach has yet to emerge among decision makers in the UK regarding the transparent and accountable use of COI in individual cases.

The OGN study has highlighted the widespread misunderstanding of the policy function of OGNs and hence the danger of using, out of context, the COI contained in them. The RFRL study, on the other hand, has highlighted serious concerns about the adequacy and accuracy of the use of COI in initial decision making, while both the RFRL and the Appeal Determination study illustrate the lack of transparency in the use of COI and in particular the inadequate and inconsistent referencing of materials relied upon.

While the findings of the project outlined here have raised a number of issues and concerns and have painted a fairly negative picture of the use of COI in the UK RSD context, it is intended that the forthcoming final report will form the backbone of a new project, starting summer 2008, which will address these concerns in a positive way. This new project aims to bring together different country information users from within the UK RSD context, in order to contribute to a nationwide policy debate on the (better) use of COI by advisors, government officials, experts, and the judiciary. ${ }^{53}$

\section{Notes}

1. The Immigration Advisory Service (IAS) is the UK's largest charity providing representation and advice in immigration and asylum law. The Research and Information Unit (RIU) provides a country of origin information research service for all IAS caseworkers.

2. This article is based on a paper presented on 30 May 2008 at the conference Best Practices for Refugee Status Determination: Principles and Standards for State Responsibility, at Monash University Prato Centre, Italy. As such it represents the preliminary findings of the key studies of our project, which will be presented in full in our forthcoming publication.

3. Austrian Centre for Country of Origin and Asylum Research and Documentation (ACCORD), ACCORD COI Network \& Training. Researching Country of Origin Information: A Training Manual, September 2004, 20-23, <http://www.unhcr.org/refworld/docid/42ad40184.html> (accessed June 20, 2008).

4. Convention relating to the Status of Refugees, 28 July 1951, 189 U.N.T.S. (entered into force 22 April 1954).

5. UNHCR, Handbook on Procedures and Criteria for Determining Refugee Status under the 1951 Convention and the 1967 Protocol relating to the Status of Refugees, 1 January 1992, paragraph 42, <http://www.unhcr.org/refworld/ docid/3ae6b3314.html> (accessed June 20, 2008).

6. UNHCR, Country of Origin Information: Towards Enhanced International Cooperation, February 2004, Section II. Scope and purpose of country of origin information, A. Objectives of country of origin information, <http://www. unhcr.org/refworld/docid/403b2522a.html> (accessed June 20, 2008).

7. The new Rules, based on the EU Qualification Directive, were implemented in UK domestic law by the Refugee or Person in Need of International Protection (Qualification) Regulations 2006 (SI 2525/2006).

8. Council Directive 2004/83/EC of 29 April 2004 on minimum standards for the qualification and status of third country nationals or stateless persons as refugees or as persons who otherwise need international protection and the content of the protection granted.

9. The paper was prepared by the COI-CG Working Party of the IARLJ, whose rapporteur was Hugo Storey, Senior Immigration Judge at the UK Asylum and Immigration Tribunal (AIT).

10. International Association of Refugee Law Judges, Judicial Criteria for Assessing Country of Origin Information (COI): A Checklist, Paper for 7th Biennial IARLJ World Conference, Mexico City, 6-9 November 2006, <http://www.iarlj. $\mathrm{nl} / \mathrm{cms} /$ images/stories/forms/WPPapers/Hugo\%20StoreyCountryofOriginInformationAndCountryGuidanceWP. pdf> (accessed June 20, 2008).

11. This project refers to "The use of Country of Origin Information in the Refugee Status Determination process in the 
United Kingdom," which the Research and Information Unit of the IAS is in the process of finalizing.

12. Austrian Centre for Country of Origin and Asylum Research and Documentation (ACCORD), ACCORD COI Network \& Training. Researching Country of Origin Information: A Training Manual, September 2004, 4, <http://www.unhcr. org/refworld/docid/42ad40184.html> (accessed June 20, 2008).

13. This issue has been examined in relation to the treatment of expert evidence in asylum and human rights appeals by Anthony Good; see Anthony Good, "Expert Evidence in Asylum and Human Rights Appeals: An Expert's View," International Journal of Refugee Law 16 (3): 29-32.

14. Moreover, the notion of objectivity and therefore the possibility of the existence of objective facts is itself contested by the social sciences.

15. UNHCR (1992), para. 196. See also M. Symes and P. Jorro, "The Standard of Proof," chap. 2.1 in Asylum Law and Practice (Surrey: Butterworths LexisNexis, 2003); and Austrian Centre for Country of Origin and Asylum Research and Documentation (ACCORD), ACCORD COI Network \& Training. Researching Country of Origin Information: A Training Manual, September 2004, 20, <http://www.unhcr. org/refworld/docid/42ad40184.html> (accessed June 20, 2008).

16. See, for example, ACCORD and International Association of Refugee Law Judges.

17. UK Border Agency, Policy and Law: Guidance and Instructions, <http://www.ind.homeoffice.gov.uk/policyandlaw/ guidance/> (accessed: April 23, 2008).

18. UK Border Agency, Policy and Law: Guidance and Instructions: Country Specific Asylum Policy, <http://www. ind.homeoffice.gov.uk/policyandlaw/guidance/csap/> (accessed: April 23, 2008).

19. Ibid.

20. Advisory Panel on Country Information, Eighth Meeting, 06 March 2007: APCI.8.3 Operational Guidance Notes, March 6, 2007, <http://www.apci.org.uk/PDF/APCI.8.3\%20 OGNs.pdf $>$ (accessed: June 20, 2008).

21. The note was written as a response to a suggestion made by the Chair of the APCI that COI material could be extracted from OGNs to enable the APCI to review this.

22. Ibid., Conclusion \& Home Office response.

23. Ibid.

24. Home Office Research Study 271, Country of origin information: a user and content evaluation, September 2003, <http://www.homeoffice.gov.uk/rds/pdfs2/hors271. pdf $>$ (accessed June 20, 2008).

25. The APCI is a statutory body whose function is to review and provide advice about the COI material produced by the Home Office. For access to minutes of their meetings please visit: <http://www.apci.org.uk/>.

26. The Home Office produces COI Reports (from now on Home Office COIS Reports) on the twenty countries which generate the most asylum applications in the UK; these re- ports have been published twice yearly since 1997, but will be updated on a more frequent basis from October 2006. The COI reports are "detailed summaries compiled from material produced by a wide range of external information sources [ ... ] Each report focuses on the main asylum and human rights issues in the country, but also provides background information on geography, economy and history." For more information and to access all COI Reports, see <http://www.homeoffice.gov.uk/rds/country_reports. html> (accessed: April 23, 2008).

COI Bulletins (from now on Home Office COIS Bulletins) are produced on an ad hoc basis in response to emerging events or in relation to a country for which a COI Report is not produced. For more information and to access the COI Bulletins, see <http://www.homeoffice.gov.uk/rds/ country_reports.html> (accessed: April 23, 2008).

COI Key Documents (from now on Home Office COIS Key Documents) are produced for countries that generate fewer asylum applications and bring together all the main source documents that would be provided with a COI Report, but with a brief country profile and index rather than an actual report. For more information and to access the COI Key Documents, see <http://www.homeoffice.gov.uk/ rds/country_reports.html> (accessed: April 23, 2008).

27. In September 2003 the IAS released an analysis of the Home Office Country Assessments (HOCA) produced by the then Country Information and Policy Unit (CIPU), in April 2003. Until 1 June 2005 the country information and policy functions were carried out by one department within the Home Office, the CIPU. In December 2004 these two functions were internally separated until, in June 2005, the country information function was transferred to the Research, Development, and Statistics Directorate (RDS). See Advisory Panel on Country Information (APCI), Home Office Organisation Changes, September 2005, <http:// www.apci.org.uk/PDF/apci51.pdf> (accessed June 20, 2008). The IAS report, Home Office Country Assessments: An Analysis (IAS analysis), concluded that the HOCA contained numerous inaccuracies and are therefore frequently misleading. In addition to this, IAS established that the country information referred to in the HOCA had in places been used very selectively to paint a more positive picture of country conditions than the original sources suggested. IAS, Home Office Country Assessments: An Analysis, September 2003 and its December 2003 Addendum, <http:// www.iasuk.org/C2B/document_tree/ViewADocument. asp? ID $=259 \&$ CatID $=60>$ (accessed June 20, 2008).

28. See for example ACCORD.

29. Advisory Panel on Country Information, Eighth Meeting, 06 March 2007: APCI.8.3 Operational Guidance Notes, March 6, 2007, Conclusion \& Home Office response, <http://www.apci.org.uk/PDF/APCI.8.3\%20OGNs.pdf> (accessed: June 20, 2008).

30. Ibid., Home Office response. To date (16 May 2008) two out of the existing OGNs do not have any corresponding COI 
product. Any discussion surrounding the validity of having Home Office COI Key Documents falls unfortunately outside of the realm of this article.

31. The appeal determinations study is not completed yet.

32. Colleagues from the Irish Refugee Documentation Centre and solicitors from Canada informed researchers from the Research and Information Unit of the IAS during informal discussions in March and May 2008, respectively, that in several instances they witnessed immigration judges referring to the country information contained in OGNs to substantiate their determinations.

33. ECtHR, Salah Sheekh v. The Netherlands, no. 1948/04, 11/01/2007.

34. ECtHR, Salah Sheekh v. The Netherlands, no. 1948/04, 11/01/2007, s. 110, 111, 142, 147.

35. Immigration and Refugee Board of Canada, Responses to Information Requests (RIRs)-Angola, AGO102410.E, March 22, 2007, <http://www.cisr-irb.gc.ca/en/research/ $\mathrm{rir} /$ ?action $=$ record.viewrec $\&$ gotorec $=451055>$ (accessed June 20, 2008).

36. Immigration and Refugee Board of Canada, Responses to Information Requests (RIRs)-Albania, ALB101493.E, September 8, 2006, <http://www.irb-cisr.gc.ca/en/research/rir/?action=record.viewrec\&gotorec $=450467>$ (accessed June 20, 2008).

37. A discrete piece of research would be needed to investigate further the extend of which the use of country information contained in OGNs is used in RIRs produced by the IRBC.

38. UK Home Office, Asylum Policy Instructions, Assessing the Asylum Claim, October 2006, <http://www.bia. homeoffice.gov.uk/sitecontent/documents/policyandlaw/asylumpolicyinstructions/apis/assessingtheclaim. pdf? view=Binary $>$ (accessed June 20, 2008).

39. Grants of asylum at the initial stage are not made with an equivalent letter. Therefore the Research and Information Unit of the IAS does not have a direct means of assessing the use of COI in successful applications.

40. The Medical Foundation study examined RFRLs " ... as evidence of full and reasoned decisions on asylum claims," reporting on, among other issues, the relationship between the content of the RFRL in cases from Cameroon and the various sources of country of origin information available to the Home Office at the time of the decision, including the Home Office's own Country Assessments on Cameroon; Medical Foundation for the Care of Victims of Torture, "Right First Time? Home Office Asylum Interviewing and Reasons for Refusal Letters," February 2004, <http://www. torturecare.org.uk/publications/reports/283> (accessed June 20, 2008).

41. The QI Project is a joint IND/UNHCR initiative which monitors the quality of asylum decisions at first instance. UNHCR staff members have been based in Lunar House since August 2004 and are involved in the assessment of asylum decisions and interviews. For more information, see <http://www.bia.homeoffice.gov.uk/sitecontent/docu- ments/policyandlaw/asylumpolicyinstructions/apis/unhcr. pdf?view=Binary $>$ (accessed June 20, 2008).

42. From 5 March 2007, all new asylum applicants will come within the NAM. Any case not formally within the NAM by 5 March 2007 will be dealt with by the separate Legacy Directorate; Refugee Council Briefing, The New Asylum Model, March 2007, <http://www.refugeecouncil.org.uk/ policy/briefings/2007/nam.htm> (accessed June 20, 2008).

43. RFRLs relating to Zimbabwe stand out in this particular sample; out of a total of twenty-four, seven RFRLs made no reference to COI. Leaving aside more case and profile specific issues, five of these seven cases concerned risk to and therefore treatment of family members of MDC supporters in Zimbabwe; two concerned sexual violence related to political violence, and one had the additional issue of risk to those involved in writing dissident articles for the foreign press. Cross-cutting issues of relevance to all these cases, but for which there was no reference to COI, were the levels of political violence in the country and the situation on return for failed asylum seekers.

Similarly the three cases from Iran which made no use of COI were concerned with, among other issues, those who are imputed to have anti-regime political opinions, the treatment of those involved in the distribution of dissident materials, and the availability of a fair trial; while those from DRC and Somalia concerned treatment of people from a particular ethnic group by non-government agents and protection available.

44. RFRLs vary in length but on average they consist of from twenty to forty paragraphs.

45. It should be noted that direct reference to COIS Reports was recorded in forty-four separate RFRLS; in the case of reference to the Home Office COIS case specific research service and "Other sources," incidence of use was recorded, which includes reference to more than one type of source in the same RFRL.

46. Eighty-three RFRLs in total minus fourteen RFRLs which made no reference to COI.

47. As opposed to the date of the Home Office COIS Report, which is not the same thing.

48. Home Office, Asylum Process Manual, Chapter 3: Implementing decisions, para.14.4.2 Disclosure in the credibility section, <http://www.bia.homeoffice.gov.uk/sitecontent/ documents/policyandlaw/asylumprocessguidance/implementingandservingdecision/> (accessed June 20, 2008).

49. UNHCR, (QI) Quality Initiative Project, First Report to the Minister; A UNHCR review of the UK Home Office Refugee Status Determination Procedures, February 2005, $<$ http://www.ukba.homeoffice.gov.uk/sitecontent/documents/aboutus/reports/unhcrreports/qualityinitiative/unhcrreport1.pdf?view=Binary $>$ (accessed June 20, 2008).

50. UNHCR, (QI) Quality Initiative Project, Second Report to the Minister, February 2006, para.2.2.9, <http://www. ukba.homeoffice.gov.uk/sitecontent/documents/abou- 
tus/reports/unhcrreports/qualityinitiative/unhcrreport2. pdf? view=Binary $>$ (accessed June 20, 2008).

51. For a thorough exploration of the issues raised by the introduction of Country Guidance cases see: Colin Yeo, ed., Country Guideline Cases: Benign and Practical? (London: Immigration Advisory Service, 2005).

52. The Country Information and Policy Unit (CIPU) comprised the two units which became the COI Service and the Country Specific Asylum Policy Team in December 2004, and was part of the Asylum Policy and Appeals Directorate. For more information see: <http://www.homeoffice.gov.uk/ about-us/freedom-of-information/released-information/ foi-archive-immigration/6494-COIS-CIPU?view=Html $>$.

53. If you would like to find out more about this upcoming project please contact the Research and Information Unit of the IAS at $<$ research@iasuk.org $>$.
Jo Pettitt, Laurel Townhead and Stephanie Huber are all Research and Information Officers at the Research and Information Unit (RIU) of the Immigration Advisory Service (IAS) in London, UK. The IAS is the UK's largest charity providing representation and advice in immigration and asylum law, whilst the RIU provides a country of origin information research service for all IAS caseworkers.

Special thanks to Amanda Shah for her contribution to the project and Elizabeth Williams for her helpful comments on earlier drafts. 